\author{
Zhunussova Zh.Kh.
}

\author{
Al-Farabi Kazakh National University Republic of Kazakhstan, Almaty \\ E-mail: Zhanat.Zhunusova@kaznu.kz
}

\title{
Soliton immersion for nonlinear Schrodinger equation with gravity
}

One of the developed directions of mathematics is studying of nonlinear differential equations in partial derivatives. Investigation in this area is topical, since the results get the theoretical and practical applications. There are some different approaches for solving of the equations. Methods of the theory of solitons allow to construct the solutions of the nonlinear differential equations in partial derivatives. One of the methods for solving of the equations is the inverse scattering method. The aim of the work is to construct a surface corresponding to a regular onesolitonic solution of the nonlinear Schrodinger equation with gravity in $(1+1)$-dimension. In this work the nonlinear Schrodinger equation with gravity in $(1+1)$-dimensions, as well as solitonic immersion in FokasGelfand sense are considered. According to the approach the nonlinear differential equations in $(1+1)$-dimension are given in the form of zero curvature condition and are compatibility condition of the linear system equations, i.e. Lax representation. In this case there is a surface with immersion function. The surface defined by the immersion function is identified to the surface in threedimensional space. Surface with coefficients of the first fundamental form corresponding to the regular onesolitonic solution of the nonlinear Schrodinger equation is found by soliton immersion. Key words: nonlinear equation, immersion, surface, solitonic solution, fundamental form, zero curvature condition.

Жунусова Ж.Х.

\section{Солитонная иммерсия нелинейного уравнения Шредингера с притяжением}

Одним из развивающихся направлений математики является исследование нелинейных дифференциальных уравнений в частных производных. Исследование в данном направлений актуально, так как результаты находят теоретические и практические применения. Существуют различные подходы для решения данных уравнении. Методы теории солитонов позволяют построить решения нелинейных дифференциальных уравнений в частных производных. Одним из методов для разрешения вышеуказанных уравнений является метод обратной задачи рассеяния. Цель данной работы построение поверхности соответствующей регулярному односолитонному решению нелинейного уравнения Шредингера с притяжением в $(1+1)$ размерности. В данной работе рассмотрено нелинейное уравнение Шредингера с притяжением в $(1+1)$-размерности, а также солитонная иммерсия в смысле Фокаса-Гельфанда. Согласно данному подходу в $(1+1)$-мерном случае нелинейные дифференциальные уравнения в частных производных даются в виде условий нулевой кривизны и являются условием совместности системы линейных уравнений, т.е. представлении Лакса. В этом случае существует поверхность с иммерсионной функцией. Поверхность определенная посредством иммерсионной функции идентифицируется с поверхностью в трехмерном пространстве. С помощью солитонной иммерсии для регулярного односолитонного решения нелинейного уравнения Шредингера найдена поверхность с соответствующими коэффициентами первой квадратичной формы.

Ключевые слова: нелинейное уравнение, иммерсия, поверхность, солитонное решение, фундаментальная форма, условие нулевой кривизны. 
Жүнісова Ж.Х.

Тартылысы бар сызықты емес Шредингер теңдеуінің солитондық иммерсиясы

Сызықты емес дербес туындылы дифференциалдық теңдеулерді зерттеу - математиканың дамып кележатқан тарауларының бірі. Натижелердің теориялық және практикалық қолданысы болғандықтан, бұл бағыттағы зерттеулер өзекті. Бұл теңдеулерді шешу үшін әртүрлі әдістер бар. Сызықты емес дербес туындылы теңдеулердің шешімін солитондар теориясы әдістерін қолданып табуға болады. Кері сейілу әдісі - айтылған теңдеулерді шешуге арналған әдістердің бірі. Жұмыстың мақсаты - $(1+1)$-өлшемдегі сызықты емес Шредингер теңдеуінің регулярлық бір солитондық шешіміне сәйкес бет құру. Бұл жұмыста $(1+1)$-өлшемдегі сызықты емес Шредингер теңдеуі және Фокас-Гельфанд мағынасындағы солитондық иммерсия қарастырылған. (1+1)-өлшемде сызықты емес дербес туындылы дифференциалдық теңдеулер нөлдік қисықтық шарты арқылы беріледі және сызықты теңдеулердің, Лакс жұптарының шарты болып табылады. Бұл жағдайда иммерсиялық функциясы бар бет табылады. Иммерсиялық функциясы арқылы анықталған бет үш өлшемді кеңістіктегі бетпен сәйкестендіріледі.

Түйін сөздер: сызықты емес теңдеу, иммерсия, бет, солитондық шешім, фундаменталдық форма, нөлдік қисықтық шарты.

\section{Introduction}

Some nonlinear differential equations in partial derivatives are integrable and have physical interesting exact solutions, moreover these integrable equations are solved by the inverse scattering problem [1]-[6]. Investigations of the integrable equations in $(1+1)-,(2+1)$ dimensions are topical with mathematical physics point of view [2]-[5]. The integrable equations allow different kind of solutions as onesolitonic solution, domain wall, vortex etc. Moreover solutions of the integrable equations have geometric characteristics. To investigate the geometric characteristics of the solutions the theory of differential geometry of curves and surfaces are applied.

One of the well-known models is Heisenberg ferromagnetic model

$$
\mathbf{S}_{t}=\mathbf{S} \times \mathbf{S}_{x x}
$$

where $\times$ is vector product, $\mathbf{S}=\left(S_{1}, S_{2}, S_{3}\right), \mathbf{S}=S_{1}^{2}+S_{2}^{2}+S_{3}^{2}=1$.

Lakshmanan established that the model, which is applied in the physical applications, at $\mathbf{S}^{2}=+1$ is equivalence to the nonlinear Schrodinger equation with gravity in geometrical sense. This equivalence is called by Lakshmanan equivalence. We note, that Lakshmanan equivalence is developed as integrable, as nonintegrable differential equations in partial derivatives and its application domain is limited by establishing of equivalence between a spin system and some nonlinear differential equation in partial derivatives, for example Schrodinger type. We note, that for integrable nonlinear differential equations in partial derivatives the Lakshmanan equivalence does not assume knowledge of Lax representation for these equations. Now some generalizations of the Heisenberg ferromagnetic model in $(2+1)$ dimension are known. For example, in the work [5] a generalized Heisenberg ferromagnetic model is considered

$$
\begin{aligned}
& \mathbf{S}_{t}=\left(\mathbf{S} \times \mathbf{S}_{y}+u \mathbf{S}\right)_{x}, \\
& u_{x}=-\left(\mathbf{S},\left(\mathbf{S}_{x} \times \mathbf{S}_{y}\right)\right),
\end{aligned}
$$


where $\mathbf{S}$ is spin vector, $S_{1}^{2}+S_{2}^{2}+S_{3}^{2}=1, \times$ is vector product, $u$ is scalar function. According to the work [2] we identify the spin vector $\mathbf{S}$ with vector $\mathbf{r}_{x}$

$$
\mathbf{S} \equiv \mathbf{r}_{x}
$$

Then the generalized Heisenberg ferromagnetic model takes the form

$$
\begin{aligned}
& \mathbf{r}_{x t}=\left(\mathbf{r}_{x} \times \mathbf{r}_{x y}+u \mathbf{r}_{x}\right)_{x} \\
& u_{x}=-\left(\mathbf{r}_{x},\left(\mathbf{r}_{x x} \times \mathbf{r}_{x y}\right)\right) .
\end{aligned}
$$

A surface corresponding to the onesolitonic solution of the generalized Heisenberg ferromagnetic model is found in our previous works [2]

$$
\begin{gathered}
S_{3}(x, y, t)=1-\frac{2 \eta^{2}}{\eta^{2}+\xi^{2}} \operatorname{sech}^{2}\left(\chi_{1 R}\right), \\
S^{+}(x, y, t)=\frac{2 \eta}{\eta^{2}+\xi^{2}}\left[i \xi-\eta t h\left(\chi_{1 R}\right)\right] \operatorname{sech}\left(\chi_{1 R}\right), \\
\chi_{1}=\chi_{1 R}+i \chi_{1 I}, \quad \lambda_{1}=\eta+i \xi, \\
m_{1}=m_{1 R}(\rho)+i m_{1 I}(\rho), \quad m_{j}(y, t)=m_{j}(\rho), \\
\chi_{1 R}=\eta x+m_{1 R}(\rho)+c_{1 R}, \quad \rho=y+i \lambda_{j} t, \\
\chi_{1 I}=\xi x+m_{1 I}(\rho)+c_{1 I}, c=\ln \left(2 \eta / \lambda_{1}^{*}\right), \\
m_{1 R}(\rho)=\operatorname{Re}\left[m_{1}(\rho)\right], \quad m_{1 I}(\rho)=\operatorname{Im}\left[m_{1}(\rho)\right],
\end{gathered}
$$

The result is formulated and proved as the following theorem [5]

Theorem 1 The onesolitonic solution of the generalized Heisenberg ferromagnetic model can be represented by components of the vector $\mathbf{r}_{x}$, where

$$
\begin{gathered}
r_{1}=\frac{2 \eta}{\left(\eta^{2}+\xi^{2}\right) \operatorname{ch} \chi_{1 R}}+c_{1}, \\
r_{2}=\frac{2 \xi}{\eta^{2}+\xi^{2}} \operatorname{arctg}\left(\operatorname{sh} \chi_{1 R}\right)+c_{2}, \\
r_{3}=x-\frac{2 \eta}{\eta^{2}+\xi^{2}} \operatorname{th} \chi_{1 R}+c_{3},
\end{gathered}
$$

$c_{1}, c_{2}, c_{3}$ are constants. Solution in the form $\mathbf{r}_{x}$, corresponds a surface with coefficients of the first and second quadratic form

$$
\begin{gathered}
E=1, \quad G=\frac{4 m_{1 R y}^{2}}{\left(\eta^{2}+\xi^{2}\right) c h^{2} \chi_{1 R}}, \\
F=\frac{2 \eta m_{1 R y}}{\left(\eta^{2}+\xi^{2}\right) c h^{2} \chi_{1 R}}, \quad L=\frac{4 \eta^{3} \xi m_{1 R y}}{\sqrt{g}\left(\eta^{2}+\xi^{2}\right)^{2} c h^{4} \chi_{1 R}}, \\
M=\frac{4 \eta^{2} \xi m_{1 R y}^{2}}{\sqrt{g}\left(\eta^{2}+\xi^{2}\right)^{2} c h^{4} \chi_{1 R}}, \quad N=\frac{4 \eta \xi m_{1 R y}^{3}}{\sqrt{g}\left(\eta^{2}+\xi^{2}\right)^{2} c h^{4} \chi_{1 R}} .
\end{gathered}
$$


Thus, we have used the unified spin approach for investigating of geometric characteristics of the solution of nonlinear equation.

In this work we consider soliton immersion in Fokas-Gelfand sense [3]. In the modern literature the notion of immersion is widely expanded and related not only to the soliton theory. It is a transition from sophisticated origin problem to the simple problem.

\section{Soliton immersion}

According to the Fokas-Gelfand [3] work we present the description of the soliton immersion. In $(1+1)$-dimension the nonlinear differential equations are given in the form of zero curvature condition

$$
U_{t}-V_{x}+[U, V]=0,
$$

where $[U, V]=U V-V U$, the matrix $U$ is prescribed, and matrix $V$ is expressed in the terms of elements matrix $U$.

One of the well-known nonlinear models is nonlinear Schrodinger equation with gravity which is important for physical applications

$$
i \psi_{t}+\psi_{x x}+2 \beta|\psi|^{2} \psi=0
$$

where $\beta=+1, \psi$ is complex function.

Such nonlinear differential equations (1) are compatibility condition of the linear systems

$$
\phi_{x}=U \phi, \phi_{t}=V \phi
$$

In this case there exists a surface with immersion function $P(x, t)$ defined by formulas $\frac{\partial P}{\partial x}=\phi^{-1} X \phi, \frac{\partial P}{\partial t}=\phi^{-1} Y \phi$. The surface defined by $P(x, t)$ identified to the surface in threedimensional space defined by coordinates $x_{j}=P_{j}(x, t), \quad j=1,2,3$. Frame on the surface is given by triple [3]

$$
\frac{\partial P}{\partial x}=\phi^{-1} X \phi, \quad \frac{\partial P}{\partial t}=\phi^{-1} Y \phi, \quad N=\phi^{-1} J \phi,
$$

where $J=\frac{[X, Y]}{|[X, Y]|}, \quad|X|=\sqrt{<X, X>}$. Here by definition

$$
<X, Y>=-\frac{1}{2} \operatorname{tr}(X Y)
$$

where $X, Y$ are some matrixes. The first and second fundamental forms in the Fokas-Gelfand sense are given as

$$
\begin{gathered}
I=<X, X>d x^{2}+2<X, Y>d x d t+<Y, Y>d t^{2}, \\
I I=<\frac{\partial X}{\partial x}+[X, U], J>d x^{2}+2<\frac{\partial X}{\partial t}+[X, V], J>d x d t+<\frac{\partial Y}{\partial t}+[Y, V], J>d t^{2} .
\end{gathered}
$$

As it is shown in the work [3] the immersion function $P$ can be defined as

$$
P=\gamma_{0} \phi^{-1} \phi_{\lambda}+\phi^{-1} M_{1} \phi=\sum_{j=1}^{3} P_{j} f_{j},
$$


where $M_{1}$ is matrix function defined by $\lambda, x, t$. Здесь $f_{j}=-\frac{i}{2} \sigma_{j}$ is corresponding algebra basis, $\sigma_{j}$ are Pauli matrixes and $\left[f_{i}, f_{j}\right]=f_{k}$. In this case, $X, Y$ can be written

$$
X=\gamma_{0} U_{\lambda}+M_{1 x}+\left[M_{1}, U\right], Y=\gamma_{0} V_{\lambda}+M_{1 t}+\left[M_{1}, V\right] .
$$

Let the matrixes $X, Y, J$ have the forms

$$
X=\left(\begin{array}{ll}
a_{11} & a_{12} \\
a_{21} & a_{22}
\end{array}\right), \quad Y=\left(\begin{array}{ll}
b_{11} & b_{12} \\
b_{21} & b_{22}
\end{array}\right), \quad J=\left(\begin{array}{ll}
c_{11} & c_{12} \\
c_{21} & c_{22}
\end{array}\right) .
$$

In this case elements of the matrix $J$ are expressed through elements of the matrix $X$ and $Y$ in correspondence to the following formulas

$$
\begin{aligned}
& c_{11}=\frac{a_{12} b_{21}-b_{12} a_{21}}{|[X, Y]|}, \quad c_{21}=\frac{a_{21}\left(b_{11}-b_{22}\right)+b_{21}\left(a_{22}-a_{11}\right)}{|[X, Y]|}, \\
& c_{12}=\frac{b_{12}\left(a_{11}-a_{22}\right)+a_{12}\left(b_{22}-b_{11}\right)}{|[X, Y]|}, \quad c_{22}=\frac{a_{21} b_{12}-b_{21} a_{12}}{|[X, Y]|} .
\end{aligned}
$$

Then the first fundamental form (4) of the surface $I=E d x^{2}+2 F d x d t+G d t^{2}$, where

$$
\begin{gathered}
E=-\frac{1}{2}\left(a_{11}^{2}+2 a_{12} a_{21}+a_{22}^{2}\right), \quad F=-\frac{1}{2}\left(a_{11} b_{11}+a_{12} b_{21}+a_{21} b_{12}+a_{22} b_{22}\right), \\
G=-\frac{1}{2}\left(b_{11}^{2}+2 b_{12} b_{21}+b_{22}^{2}\right) .
\end{gathered}
$$

As example of the soliton equation leading to the immersion we consider nonlinear Schrodinger equation (2). In this case the matrixes $U, V$ take the forms [4]

$$
\begin{gathered}
U=\frac{\lambda \sigma_{3}}{2 i}+U_{0}, U_{0}=i\left(\begin{array}{cc}
0 & \bar{q} \\
q & 0
\end{array}\right) \\
V=\frac{i \lambda^{2}}{2} \sigma_{3}+i|q|^{2} \sigma_{3}-i \lambda\left(\begin{array}{cc}
0 & \bar{q} \\
q & 0
\end{array}\right)+\left(\begin{array}{cc}
0 & \bar{q}_{x} \\
-q_{x} & 0
\end{array}\right) .
\end{gathered}
$$

The lemma is valid.

$\mathrm{L}$ e $\mathrm{m} \mathrm{m}$ a. The second fundamental form in Fokas-Gelfand sense corresponding to the regular onesolitonic solution $q$ of the nonlinear Schrodinger equation has the form

$$
I I=L d x^{2}+2 M d x d t+N d t^{2},
$$

where

$$
\begin{gathered}
L=-\frac{1}{2}\left\{a_{11 x} c_{11}+a_{12 x} c_{21}+a_{21 x} c_{12}+a_{22 x} c_{22}-\lambda i\left(a_{21} c_{12}-a_{12} c_{21}\right)+\right. \\
\left.+i q\left(a_{12} c_{11}+a_{22} c_{12}-a_{11} c_{12}-a_{12} c_{22}\right)+i \bar{q}\left(a_{21} c_{22}+a_{11} c_{21}-a_{22} c_{21}-a_{21} c_{11}\right)\right\} \\
M=-\frac{1}{2}\left\{a_{11 t} c_{11}+a_{12 t} c_{21}+a_{21 t} c_{12}+a_{22 t} c_{22}+i\left(\lambda^{2}+2|q|^{2}\right)\left(a_{21} c_{12}-a_{12} c_{21}\right)+\right. \\
+\left(q_{x}+\lambda i q\right)\left(a_{11} c_{12}+a_{12} c_{22}-a_{12} c_{11}-a_{22} c_{12}\right)+ \\
\left.+\left(\bar{q}_{x}-\lambda i \bar{q}\right)\left(a_{11} c_{21}+a_{21} c_{22}-a_{21} c_{11}-a_{22} c_{21}\right)\right\}
\end{gathered}
$$




$$
\begin{gathered}
N=-\frac{1}{2}\left\{b_{11 t} c_{11}+b_{12 t} c_{21}+b_{21 t} c_{12}+b_{22 t} c_{22}+i\left(\lambda^{2}+2|q|^{2}\right)\left(b_{21} c_{12}-b_{12} c_{21}\right)+\right. \\
+\left(q_{x}+\lambda i q\right)\left(b_{11} c_{12}+b_{12} c_{22}-b_{12} c_{11}-b_{22} c_{12}\right)+ \\
\left.+\left(\bar{q}_{x}-\lambda i \bar{q}\right)\left(b_{11} c_{21}+b_{21} c_{22}-b_{21} c_{11}-b_{22} c_{21}\right)\right\}
\end{gathered}
$$

P r o o f. We substitute the matrixes (6), (10) to (5). After some algebra we get (11), (12a)-(12c). The lemma is proved.

\section{Theorem about surface to regular onesolitonic solution}

We consider a particular case at $\gamma_{0}=1, \quad M_{1}=0$. In the case we get

$$
X=U_{\lambda}=\frac{1}{2 i}\left(\begin{array}{cc}
1 & 0 \\
0 & -1
\end{array}\right), Y=V_{\lambda}=-i\left(\begin{array}{cc}
-\lambda & \bar{q} \\
q & \lambda
\end{array}\right), J=\left(\begin{array}{cc}
0 & -\frac{\bar{q}}{\sqrt{q \bar{q}}} \\
\frac{q}{\sqrt{q \bar{q}}} & 0
\end{array}\right),
$$

and $P=\phi^{-1} \phi_{\lambda}$. In order to calculate the explicit expressions for immersion function $P$ we consider the regular onesolitonic solution of the nonlinear Schrodinger equation which has the form [4]

$$
q(x, t)=2 \eta \frac{\exp \left(-2 i \xi x-4 i\left(\xi^{2}-\eta^{2}\right) t-i \delta\right)}{\operatorname{ch}\left[2 \eta\left(x+4 \xi t-x_{0}\right)\right]},
$$

where $x_{0}=\frac{1}{2 \eta} \ln \left|\frac{m_{02}}{m_{01}}\right|, \delta=\operatorname{argm}_{02}-\operatorname{argm}_{01}, \xi=\operatorname{Re} \lambda, \eta=\operatorname{Im} \lambda$.

Theorem. Regular onesolitonic solution of the nonlinear Schrodinger equation corresponds to the surface in Fokas-Gelfand sense with the coefficients of the first fundamental form

$$
\begin{aligned}
& E=\frac{64 \eta^{2}\left(\xi^{2}+\eta^{2}\right)}{(\lambda-\bar{\lambda})^{4} \operatorname{ch}^{2}\left[2 \eta\left(x+4 \xi t-x_{0}\right)\right]}, \\
& F=\frac{128 \eta^{2} \xi\left(\xi^{2}+\eta^{2}\right)}{(\lambda-\bar{\lambda})^{4} \operatorname{ch}^{2}\left[2 \eta\left(x+4 \xi t-x_{0}\right)\right]}, \\
& G=\frac{256 \eta^{2}\left(\xi^{2}+\eta^{2}\right)^{2}}{(\lambda-\bar{\lambda})^{4} \operatorname{ch}^{2}\left[2 \eta\left(x+4 \xi t-x_{0}\right)\right]},
\end{aligned}
$$

where $\lambda_{1}=$ const.

$\mathrm{P}$ r o o f. Solution of the linear system we find in the form

$$
\psi=\phi e^{-\left(\frac{\lambda \sigma_{3}}{2 i} x+\frac{i \lambda^{2}}{2} \sigma_{3} t\right)} .
$$

Taking into account (16) and applying (10) we get

$$
\psi_{x}=\left(\frac{\lambda \sigma_{3}}{2 i}+U_{0}\right) \psi-\psi \frac{\lambda \sigma_{3}}{2 i}=\frac{\lambda \sigma_{3}}{2 i} \psi-\psi \frac{\lambda \sigma_{3}}{2 i}+U_{0} \psi=\left[\frac{\lambda \sigma_{3}}{2 i}, \psi\right]+U_{0} \psi
$$

We take

$$
\psi=I-\frac{\tilde{A}}{\lambda-\lambda_{1}^{*}} \text {, where } \tilde{A}=\left(\begin{array}{cc}
\tilde{a} & \tilde{b} \\
\tilde{c} & \tilde{d}
\end{array}\right), I=\left(\begin{array}{cc}
1 & 0 \\
0 & 1
\end{array}\right), \quad \lambda_{1}^{*} \text { - const. }
$$


We substitute (18) to (17)

$$
\psi_{x}=U_{0}-\frac{U_{0} \tilde{A}}{\lambda-\lambda_{1}^{*}}-\frac{1}{2 i}\left[\sigma_{3}, \tilde{A}\right]-\frac{\lambda_{1}^{*}}{2 i\left(\lambda-\lambda_{1}^{*}\right)}\left[\sigma_{3}, \tilde{A}\right] .
$$

On the other hand from (18) follows

$$
\psi_{x}=-\frac{\tilde{A}_{x}}{\lambda-\lambda_{1}^{*}}
$$

From (19) and (20) we get

$$
-\frac{\tilde{A}_{x}}{\lambda-\lambda_{1}^{*}}=U_{0}-\frac{U_{0} \tilde{A}}{\lambda-\lambda_{1}^{*}}-\frac{1}{2 i}\left[\sigma_{3}, \tilde{A}\right]-\frac{\lambda_{1}^{*}}{2 i\left(\lambda-\lambda_{1}^{*}\right)}\left[\sigma_{3}, \tilde{A}\right] .
$$

Thus

$$
\tilde{A}_{x}=U_{0} \tilde{A}+\frac{\lambda_{1}^{*}}{2 i}\left[\sigma_{3}, \tilde{A}\right], U_{0}=\frac{1}{2 i}\left[\sigma_{3}, A\right]
$$

We note, that

$$
\left[\sigma_{3}, \tilde{A}\right]=\sigma_{3} \tilde{A}-\tilde{A} \sigma_{3}=2\left(\begin{array}{cc}
0 & \tilde{b} \\
-\tilde{c} & 0
\end{array}\right) .
$$

Then we substitute (23) to (7) and get

$$
U_{0}=\frac{1}{i}\left(\begin{array}{cc}
0 & \tilde{b} \\
-\tilde{c} & 0
\end{array}\right)
$$

Substituting (23) to (22) we get

$$
\left(\begin{array}{cc}
\tilde{a}_{x} & \tilde{b}_{x} \\
\tilde{c}_{x} & \tilde{d}_{x}
\end{array}\right)=\frac{1}{i}\left(\begin{array}{cc}
\tilde{b} \tilde{c} & \tilde{b} \tilde{d} \\
-\tilde{c} \tilde{a} & -\tilde{c} \tilde{b}
\end{array}\right)+\frac{\lambda_{1}^{*}}{i}\left(\begin{array}{cc}
0 & \tilde{b} \\
-\tilde{c} & 0
\end{array}\right),
$$

From (10) and (24) we get

$$
i\left(\begin{array}{cc}
0 & \bar{q} \\
q & 0
\end{array}\right)=\frac{1}{i}\left(\begin{array}{cc}
0 & b \\
-c & 0
\end{array}\right) \Rightarrow\left\{\begin{array} { c } 
{ i \overline { q } = \frac { 1 } { i } b } \\
{ i q = - \frac { 1 } { i } c }
\end{array} \Rightarrow \left\{\begin{array}{c}
b=-\bar{q} \\
c=q .
\end{array}\right.\right.
$$

Therefore, we have found the matrix $\tilde{A}$ in the explicit form with components (25). Using (14) we get

$$
\tilde{a}=i 2 \eta t h\left[2 \eta\left(x+4 \xi t-x_{0}\right)\right]+c_{1} .
$$

From (25) follows $\tilde{a}=-\frac{i \tilde{c}_{x}}{c}-\lambda_{1}^{*} \Rightarrow \tilde{a}=-\frac{1}{i} \int \bar{q} q d x$. Using (14) we get

$$
\tilde{a}_{x}=\frac{1}{i} \tilde{b} \tilde{c} \Rightarrow \tilde{a}_{x}=\frac{1}{i}(-\bar{q}) q
$$

Then

$$
\tilde{a}=-\frac{i q_{x}}{q}-\lambda_{1}^{*}
$$


Consequently, from (25), (26) follow

$$
\tilde{d}=\frac{i \tilde{b}_{x}}{\tilde{b}}-\lambda_{1}^{*} \Rightarrow \tilde{d}=\frac{i(-\bar{q})_{x}}{(-\bar{q})}-\lambda_{1}^{*} \Rightarrow \tilde{d}=\frac{i \bar{q}_{x}}{\bar{q}}-\lambda_{1}^{*} .
$$

From (25), (26) follow

$$
\tilde{d}_{x}=-\frac{1}{i} \tilde{c} \tilde{b}
$$

Moreover from (23), (31) follow

$$
\tilde{d}=\frac{1}{i} \int q \bar{q} d x
$$

Taking into account (22), we get (28) in the form

$$
\tilde{d}=-\tilde{a} .
$$

Therefore,

$$
\tilde{a}=-i 2 \eta t h\left[2 \eta\left(x+4 \xi t-x_{0}\right)\right]+c_{1} .
$$

Thus, the matrix $\tilde{A}$ for regular onesolitonic solution (14) of the nonlinear Schrodinger equation takes the form

$$
\tilde{A}=\left(\begin{array}{cc}
i 2 \eta t h\left[2 \eta\left(x+4 \xi t-x_{0}\right)\right]+c_{1} & -2 \eta \frac{\exp \left\{i\left(2 \xi x+4\left(\xi^{2}-\eta^{2}\right) t+\delta\right)\right\}}{c h\left[2 \eta\left(x-x_{0}+4 \xi t\right)\right]} \\
2 \eta \frac{\exp \left\{-i\left(2 \xi x+4\left(\xi^{2}-\eta^{2}\right) t+\delta\right)\right\}}{\operatorname{ch}\left[2 \eta\left(x-x_{0}+4 \xi t\right)\right]} & -i 2 \eta t h\left[2 \eta\left(x+4 \xi t-x_{0}\right)\right]+c_{1}
\end{array}\right)
$$

We take $\phi=I-\frac{A}{\left(\lambda-\lambda_{1}\right)^{2}}$, where $\lambda_{1}$ is constant, then from (13) we get

$$
P=\phi^{-1} \phi_{\lambda}=\left(I+\frac{\tilde{A}}{\lambda-\lambda_{1}}\right) \frac{\tilde{A}}{\left(\lambda-\bar{\lambda}_{1}\right)^{2}} .
$$

On the other hand we get

$$
P=\sum_{j=1}^{3} P_{j} f_{j}=-\frac{i}{2} \sum_{j=1}^{3} P_{j} \sigma_{j}=\left(\begin{array}{cc}
-\frac{i}{2} P_{3} & -\frac{i}{2} P_{1}-\frac{1}{2} P_{2} \\
-\frac{i}{2} P_{1}+\frac{1}{2} P_{2} & \frac{i}{2} P_{3}
\end{array}\right) .
$$

From (36), (37) by (31) we get $P_{3}=\frac{2 i \tilde{a}}{\left(\lambda-\bar{\lambda}_{1}\right)^{2}}$. With help of (33) we find $P_{3}$ in the explicit form for regular onesolitonic solution of the nonlinear Schrodinger equation

$$
P_{3}=-\frac{4 \eta}{(\lambda-\bar{\lambda})^{2}} \operatorname{th}\left[2 \eta\left(x+4 \xi t-x_{0}\right)\right]+c_{1} .
$$

From (36), (37) we get $P_{2}=\frac{\tilde{c}-\tilde{b}}{\left(\lambda-\bar{\lambda}_{1}\right)^{2}}$. Thus

$$
P_{1}=\frac{i(\tilde{c}+\tilde{b})}{\left(\lambda-\bar{\lambda}_{1}\right)^{2}}, \quad P_{2}=\frac{(\tilde{c}-\tilde{b})}{\left(\lambda-\bar{\lambda}_{1}\right)^{2}}, \quad P_{3}=\frac{2 i \tilde{a}}{\left(\lambda-\bar{\lambda}_{1}\right)^{2}}
$$

From (36), (14) using the well-known formulas

$$
\operatorname{sh} \zeta=\frac{e^{\zeta}-e^{-\zeta}}{2} ; \operatorname{ch} \zeta=\frac{e^{\zeta}+e^{-\zeta}}{2} ; \cos \zeta=\frac{e^{i \zeta}+e^{-i \zeta}}{2} ; \sin \zeta=\frac{e^{i \zeta}-e^{-i \zeta}}{2 i},
$$


where $\zeta=2 \eta\left(x-x_{0}+4 \xi t\right)$ we obtain the values for the components $P_{1}, P_{2}$ of the matrix $P$

$$
\begin{aligned}
& P_{1}=\frac{4 \eta \sin \left(2 \xi x+4\left(\xi^{2}-\eta^{2}\right) t+\delta\right)}{(\lambda-\bar{\lambda})^{2} \operatorname{ch}\left[2 \eta\left(x+4 \xi t-x_{0}\right)\right]}, \\
& P_{2}=\frac{4 \eta \cos \left(2 \xi x+4\left(\xi^{2}-\eta^{2}\right) t+\delta\right)}{(\lambda-\bar{\lambda})^{2} \operatorname{ch}\left[2 \eta\left(x+4 \xi t-x_{0}\right)\right]} .
\end{aligned}
$$

Then we calculate coefficients of the first fundamental form by formula

$$
E=P_{1 x}^{2}+P_{2 x}^{2}+P_{3 x}^{2} \text {. }
$$

We calculate the derivatives $P_{1 x}, P_{2 x}, P_{3 x}$. The square of the first derivatives is substituted to (41), then

$$
E=\frac{64 \eta^{2}\left(\xi^{2}+\eta^{2}\right)}{(\lambda-\bar{\lambda})^{4} \operatorname{ch}^{2}\left[2 \eta\left(x+4 \xi t-x_{0}\right)\right]} .
$$

By the similar way we find

$$
F=P_{1 x} P_{1 t}+P_{2 x} P_{2 t}+P_{3 x} P_{3 t}, \quad G=P_{1 t}^{2}+P_{2 t}^{2}+P_{3 t}^{2}
$$

we obtain the values

$$
\begin{aligned}
& F=\frac{128 \eta^{2} \xi\left(\xi^{2}+\eta^{2}\right)}{(\lambda-\bar{\lambda})^{4} \operatorname{ch}^{2}\left[2 \eta\left(x+4 \xi t-x_{0}\right)\right]} \\
& G=\frac{256 \eta^{2}\left(\xi^{2}+\eta^{2}\right)^{2}}{(\lambda-\bar{\lambda})^{4} \operatorname{ch}^{2}\left[2 \eta\left(x+4 \xi t-x_{0}\right)\right]}
\end{aligned}
$$

Theorem is proved.

\section{Conclusion}

Thus, we investigate soliton immersion in $(1+1)$-dimension. As example, we have considered $(1+1)$-dimensional nonlinear Schrodinger equation with gravity. The first fundamental form with corresponding coefficients (15) for integrable surface corresponding to regular onesolitonic solution of the nonlinear Schrodinger equation with gravity is found.

\section{References}

[1] Ablowitz M.J., Clarkson P.A. Solitons, Non-linear Evolution Equations and Inverse Scattering. - Cambridge: Cambridge University Press, 1992. - 516 p.

[2] Myrzakulov R., Vijayalakshmi S. et all. A (2+1)-dimensional integrable spin model: Geometrical and gauge equivalent counterparts, solitons and localized coherent structures // J. Phys. Lett. A., - 1997. - №233A. - P. 391-396.

[3] Ceyhan O., Fokas A.S., Gurses M. Deformations of surfaces associated with integrable Gauss-Mainardi-Codazzi equations // J. Math. Phys., - 2000. - №4. - P. 2551-2270.

[4] Makhankov V.G., Myrzakuov R. Riemann Problem on a Plane and Nonlinear Schroedinger Equation // In book "Communication of the Joint Institute for Nuclear Research,"P5-84-742, - Dubna, - 1984, - P. 6.

[5] Zhunussova Zh. Geometrical features of the soliton solution // Proceedings of the 9th ISAAC Congress, Springer, Series: Trends in Mathematics, ISBN 978-3-319-12576-3, - 2015. - P. 671-677.

[6] Zhunussova $Z$ h. Reconstruction of surface corresponding to domain wall solution // Proceeding of the forth International conference "Modern problems of Applied mathematics and information technologies, Al-Khorezmiy 2014, Samarkand, 2014. - P. 283 